\title{
Úroveň znalostí zásad laické resuscitace u pacientů po prodělané srdeční zástavě a u jejich príbuzných
}

\author{
Markéta Křečková', Ondřej Franěk², Jan Bělohlávek \\ 'Koronární jednotka, Il. interní klinika kardiologie a angiologie, Všeobecná fakultní nemocnice, Praha \\ ${ }^{2}$ Zdravotnická záchranná služba hl.m. Prahy, Praha, Česká republika
}

\section{Křečková $M$, Franěk $O$, Bělohlávek J. Úroveň znalostí zásad laické resuscitace u pacientů po prodělané srdeční zástavě a u jejich př́buzných. Cor Vasa 2011;53:x-y.}

Srdeční zástava je závažný medicínský, ale i celospolečenský problém. Přežití nemocných s mimonemocniční zástavou závisí hlavně na charakteru základního onemocnění a době zástavy oběhu. Předpokladem záchrany pacienta s dechovou či oběhovou zástavou je včasná kardiopulmonální resuscitace (KPR). Úspěšnost (KPR) dlouhodobě dosahuje cca $10 \%$, proto je nezbytná edukace široké veřejnosti v technikách provádění kardiopulmonální resuscitace. Samotné zahájení kardiopulmonální resuscitace zvyšuje šanci na přežití dvoj- až trojnásobně. Přesto není pomoc svědky někdy poskytnuta vůbec, často pro neznalost správných postupů a z obavy z vlastního selhání. Klíčová slova: Náhlá srdeční smrt - Kardiopulmonální resuscitace - Edukace

Adresa: Bc. Markéta Křečková, Koronární jednotka, II. interní klinika kardiologie a angiologie, VFN, U Nemocnice, 12801 Praha 2, e-mail: kreckovam@seznam.cz

\section{úvod}

Náhlou srdeční smrtí (NSS) umírá denně v evropské populaci více než 2500 osob. V Praze je to zhruba 10-15 př́padů denně. Až $90 \%$ př́padů je způsobeno maligními komorovými arytmiemi, které vznikají nejčastěji na podkladě organického onemocnění srdce. Náhlou smrtí jsou nejvíce ohroženi pacienti s ischemickou chorobou srdeční, kdy se její akutní i chronické formy podílejí na NSS v $80 \%$ př́padů. Při všeobecně malé účinnosti kardiopulmonální resuscitace $\mathrm{v}$ terénu tak většina pacientů umírá již při první epizodě setrvalé maligní arytmie. Náhlá srdeční smrt až v 50 \% případů vzniká jako první manifestace ischemické choroby srdeční, a to nejčastěji u mužů ve středním věku.

Přestože od prvního popisu komorové fibrilace v experimentu na psím srdci uplynulo již 161 let a od roku 1947 je známa i její terapie - defibrilace, zůstává komorová fibrilace hlavní př́íčinou náhlé smrti. Pro primární úspěšnost se u fibrilujícího pacienta jeví jako klíčový interval pro časnou defibrilaci 3-8 minut od vzniku srdeční zástavy. $\mathrm{V}$ tomto časovém úseku lze dosáhnout až $60 \%$ úspěšnosti. $Z$ úspěšně resuscitovaných $\mathrm{v}$ terénu je však $\mathrm{z}$ následné hospitalizace propuštěno pouze 5-9 \% pacientů.

Prognóza těchto pacientů s náhlou zástavou oběhu je vysoce nepř́ínivá, nikoli však beznadějná, a správný postup laických zachránců, personálu tísňových služeb i cílových zdravotnických zařízení může naději pacienta na přežití významně zvýšit.

Náhlá zástava oběhu je situace, při níž z jakéhokoli důvodu došlo $\mathrm{k}$ náhlému přerušení cirkulace krve $\mathrm{v}$ systémovém krevním oběhu. Neodkladná resuscitace je souborem na sebe navazujících léčebných postupů, které slouží k neprodlenému obnovení oběhu okysličené krve u osoby postižené náhlou zástavou oběhu s cílem uchránit před nezvratným poškozením zejména srdeční sval a mozek.

Časné zahájení kardiopulmonální resuscitace zvyšuje šanci na přežití dvoj- až trojnásobně. Přesto není pomoc někdy poskytnuta svědky vưbec, často pro neznalost správných postupů a z obavy z vlastního selhání. Současná doporučení proto byla výrazně zjednodušena s cílem usnadnit edukaci laických záchranářů. Postupy vedoucí $\mathrm{k}$ přežití pacienta jsou zahrnuty $\mathrm{v}$ „řetězci přežití, který obsahuje:

1. časné rozpoznání situace a časné zavolání kvalifikované pomoci,

2. časné zahájení kardiopumonální resuscitace,

3. časnou defibrilaci,

4. poresuscitační péči.

Moderní éra KPR se datuje od roku 1960, kdy doktor W. B. Kouwenhoven znovu objevil a přepracoval zevní masáž srdce jako postup při obnovení krevního oběhu. $\mathrm{V}$ témž roce byly do klinické praxe uvedeny defibrilátory. Profesor P. Safar prokázal, že účinnou metodu kardiopulmonální resuscitace představuje kombinace umělého dýchání z plic do plic se zevni masáži srdce. Od 70. let byla pozornost výzkumníků zaměřená na přežívání mozku v průběhu zástavy a bezprostředně po ní.

Základní diagnostické a terapeutické postupy při stavech bezprostř̌edně ohrožujících život vycházejí v současné době z doporučení konference American Heart Association z roku 1992 v USA. Mezinárodní koordinační orgán pro resuscitaci ILCOR (International Liaison Committee on Resuscitation) vydal v roce 2000 nové směrnice pro neodkladnou resuscitaci, 
Tabulka 1 Vyhodnocení odpovědí před seminářem a po něm

\begin{tabular}{|c|c|c|c|c|c|c|c|}
\hline \multirow{2}{*}{$\begin{array}{l}\text { Otázka } \\
\text { číslo }\end{array}$} & \multirow[t]{2}{*}{ Znění otázky } & \multicolumn{2}{|c|}{ \% správnosti } & \multirow{2}{*}{$\begin{array}{l}\text { Otázka } \\
\text { číslo }\end{array}$} & \multirow[t]{2}{*}{ Znění otázky } & \multicolumn{2}{|c|}{ \% správnosti } \\
\hline & & $\begin{array}{c}\text { před } \\
\text { seminářem }\end{array}$ & $\begin{array}{l}\text { po semi- } \\
\text { náři }\end{array}$ & & & $\begin{array}{c}\text { před } \\
\text { seminářem }\end{array}$ & $\begin{array}{l}\text { po semi- } \\
\text { náři }\end{array}$ \\
\hline 7 & $\begin{array}{l}\text { Jaké je správné číslo záchranné služby? } \\
\text { a) } 155 \text { a } 112 \\
\text { b) } 158 \\
\text { c) } 150\end{array}$ & 95 & 100 & 16 & $\begin{array}{l}\text { Jaká je správná frekvence při } \\
\text { srdeční masáži dospělého? } \\
\text { a) } 50 / \mathrm{min} \\
\text { b) } 90 / \mathrm{min}\end{array}$ & 13 & 40 \\
\hline \multirow[t]{2}{*}{8} & \multirow{2}{*}{$\begin{array}{l}\text { Je naší povinností poskytnout první pomoc? } \\
\text { a) ano, ukládá to zákon } \\
\text { b) ne, jestliže si myslíme, že to nezvládneme } \\
\text { c) ano, ale jen po domluvě s lékařem }\end{array}$} & \multirow[t]{2}{*}{93} & \multirow[t]{2}{*}{92} & & $\begin{array}{l}\text { c) } 100 / \mathrm{min} \\
\text { d) } 120 / \mathrm{min}\end{array}$ & & \\
\hline & & & & 17 & $\begin{array}{l}\text { Jaký je správný poměr umělého } \\
\text { dýchání a srdeční masáže }\end{array}$ & 33 & 50 \\
\hline \multirow[t]{3}{*}{9} & \multirow{3}{*}{$\begin{array}{l}\text { Zvolte správný postup při poskytování první } \\
\text { pomoci? } \\
\text { a) zjistit, zda postižený dýchá; zahájit nepřímou } \\
\text { srdeční masáž a umělé dýchání; uvolnit } \\
\text { dýchací cesty, zavolat záchrannou službu } \\
\text { b) zahájit nepřímou srdeční masáž a umělé } \\
\text { dýchání; uvolnit dýchací cesty; zavolat } \\
\text { záchrannou službu; zjistit, zda postižený } \\
\text { dýchá } \\
\text { c) zjistit, zda postižený dýchá; uvolnit dýchací } \\
\text { cesty; zavolat záchrannou službu; zahájit } \\
\text { nepřímou srdeční masáž a umělé dýchání }\end{array}$} & \multirow{3}{*}{ (1) } & \multirow[t]{3}{*}{90} & & $\begin{array}{l}\text { u dospělého? } \\
\text { a) } 1: 15 \\
\text { b) } 2: 15 \\
\text { c) } 2: 30 \\
\text { d) poměr není důležitý }\end{array}$ & & \\
\hline & & & & 18 & $\begin{array}{l}\text { Stabilizovaná poloha je? } \\
\text { a) na zádech } \\
\text { b) na boku } \\
\text { c) v polosedě }\end{array}$ & 70 & 60 \\
\hline & & & & 19 & $\begin{array}{l}\text { Do stabilizované polohy } \\
\text { ukládáme pacienty? }\end{array}$ & 38 & 21 \\
\hline \multirow[t]{2}{*}{10} & \multirow{2}{*}{$\begin{array}{l}\text { Jaké jsou příznaky poruchy vědomí? } \\
\text { a) bledost, pocení, chybí reakce na oslovení } \\
\text { b) zarudlý obličej, zrychlená řeč } \\
\text { c) ztráta dechu, otoky dolních končetin }\end{array}$} & \multirow[t]{2}{*}{95} & \multirow[t]{2}{*}{100} & & $\begin{array}{l}\text { b) když dýchá } \\
\text { c) jen pokud nepředcházel úraz }\end{array}$ & & \\
\hline & & & & 20 & Kdy přerušíme provádění srdeční & 95 & 100 \\
\hline 11 & $\begin{array}{l}\text { Jaké jsou příznaky zástavy dýchání? } \\
\text { a) zápach z úst, slinění } \\
\text { b) není pohyb hrudníku, promodrání } \\
\text { c) zrychlený puls, zarudlý obličej }\end{array}$ & 83 & 90 & & $\begin{array}{l}\text { a) po } 30 \text { minutách } \\
\text { b) nepřerušujeme do příjezdu } \\
\text { lékaře } \\
\text { c) ihned, když zjistíme, že }\end{array}$ & & \\
\hline \multirow[t]{2}{*}{12} & \multirow{2}{*}{$\begin{array}{l}\text { Jaké jsou příznaky zástavy krevního oběhu? } \\
\text { a) bolest na hrudi } \\
\text { b) zrychlený puls, zarudnutí } \\
\text { c) bezvědomí, promodrání }\end{array}$} & \multirow[t]{2}{*}{80} & \multirow[t]{2}{*}{80} & & $\begin{array}{l}\text { pacient nedýchá a nemá } \\
\text { hmatný puls }\end{array}$ & & \\
\hline & & & & 21 & $\begin{array}{l}\text { Jaká je průměrná tepová } \\
\text { frekvence u zdravého dospělého }\end{array}$ & 48 & 50 \\
\hline \multirow[t]{2}{*}{13} & \multirow{2}{*}{$\begin{array}{l}\text { Jaký výkon provádíme k uvolnění dýchacích } \\
\text { cest? } \\
\text { a) záklon hlavy a předsunutí dolní čelisti } \\
\text { b) vytažení jazyka prsty } \\
\text { c) úder do zad u osoby po vdechnutí cizího } \\
\text { tělesa }\end{array}$} & \multirow[t]{2}{*}{63} & \multirow[t]{2}{*}{79} & & $\begin{array}{l}\text { člověka? } \\
\text { a) } 50-70 \\
\text { b) } 70-80 \\
\text { c) } 90-100\end{array}$ & & \\
\hline & & & & 22 & $\begin{array}{l}\text { Víte co je automatický externí } \\
\text { defibrilátor? }\end{array}$ & 40 & 50 \\
\hline 14 & $\begin{array}{l}\text { Na kterých místech vyhmatáváme puls? } \\
\text { a) na krku } \\
\text { b) na ruce } \\
\text { c) v třísle } \\
\text { d) není to nutné, zbytečně to zdržuje }\end{array}$ & 85 & 90 & & $\begin{array}{l}\text { a) přístroj, který po nalepení } \\
\text { elektrod vyhodnotí EKG } \\
\text { a případně provede } \\
\text { elektrický výboj } \\
\text { b) přístroj používaný k zevní }\end{array}$ & & \\
\hline \multirow[t]{2}{*}{15} & \multirow{2}{*}{$\begin{array}{l}\text { Jak správně provádíme srdeční masáž } \\
\text { u dospělého? } \\
\text { a) dáváme pozor, abychom nezlomili žebra } \\
\text { b) zevní masáž provádíme oběma rukama } \\
\text { a masírujeme levou stranu hrudníku, } \\
\text { protože srdce je uloženo vlevo } \\
\text { c) zevní masáž provádíme oběma rukama } \\
\text { u dospělého ve střední části hrudníku }\end{array}$} & \multirow[t]{2}{*}{85} & \multirow[t]{2}{*}{90} & & c) prístroj k umělému dýchání & & \\
\hline & & & & 23 & $\begin{array}{l}\text { Může laik použít automatický } \\
\text { externí defibrilátor? } \\
\text { a) ano } \\
\text { b) ne } \\
\text { c) pouze pod dohledem } \\
\text { zdravotníka }\end{array}$ & 25 & 39 \\
\hline
\end{tabular}

Evropská rada pro resuscitaci tato pravidla přijala. Každých pět let se tato pravidla upravují podle nejnovějších poznatků, se snahou o jejich zjednodušení, zejména pro laickou veřejnost. Poslední změny byly v roce 2005 a v 2010 . Výuka zásad základní a rozšířené neodkladné resuscitace se na celém světě sjednocuje. Klíčem k úspěchu je rychlost, což předpokládá znalost resuscitačních metod a postupů, mezi něž patři rozpoznání poruchy základních životních funkcí - dýchání, stav vědomí, reakce na bolestivý podnět.

V posledních 15 letech se rozšiřuje užívání automatických externích defibrilátorů - přístrojů s hlasovým naváděním, které může po krátké instruktáži obsluhovat i laik. Přes řadu studií však stále není jasné, na kterých místech by se měly tyto přístroje umístit a zda to zásadním způsobem ovlivní prognózu pacientů s fibrilací komor. V současné době jsou těmito přístroji v České republice vybavovány vozy policie a hasičů.

\section{Cíl}

Zjistit úroveň znalostí o poskytování laické první pomoci u pacientů po srdeční zástavě a jejich př́ibuzných před a po kvalifikované edukaci. 


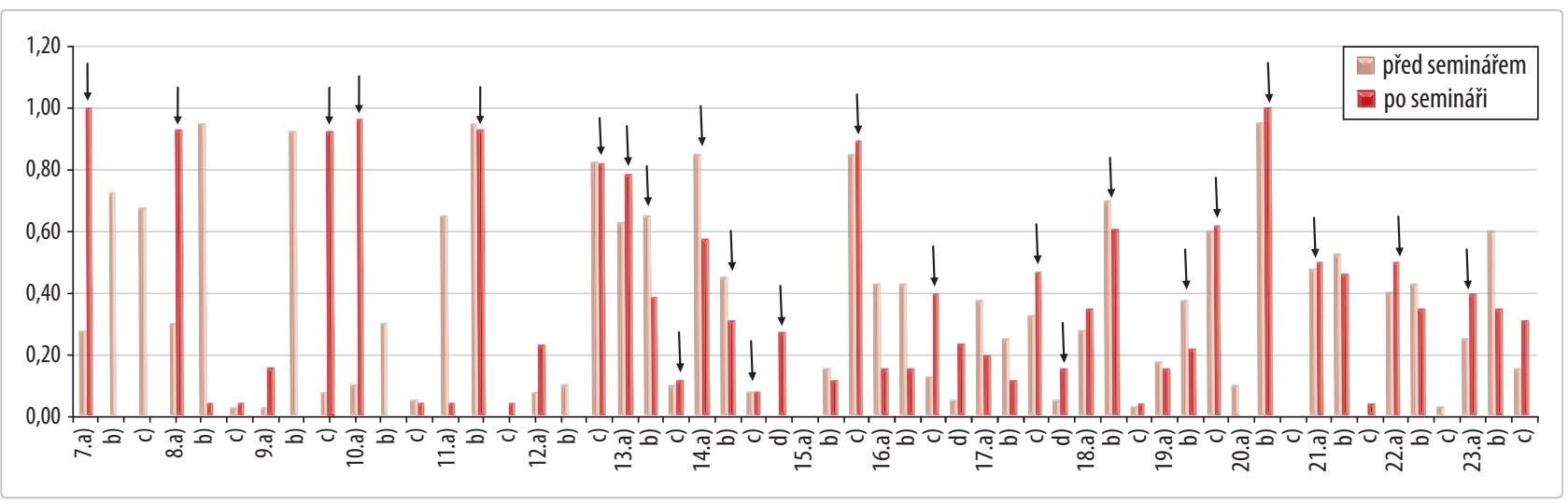

Obrázek 2 Grafické znázornění odpovědí před seminářem a po něm - šipky označují správné odpovědi

\section{Metodika}

Na naší klinice bylo od listopadu 2002 do ř́ijna 2009 hospitalizováno celkem 130 pacientů po srdeční zástavě s úspěšnou KPR. Při dohledávání osudu námi ošetřených pacientů jsme z registru zemřelých zjistili, že 80 pacientů zemřelo a 50 pacientů žije. V̌̌ech 50 pacientů jsme oslovili písemně a pozvali jsme je na ambulantní kontrolu do naší ambulance. Na tuto kontrolu přišlo 45 pacientů, pět pacientů na výzvu nereagovalo. Dále spolupracovat bylo ochotno 40 pacientů. Těmto pacientů a jejich rodinným př́slušníkům jsme zaslali dotazník o zásadách poskytování laické resuscitace (otázky a možnosti odpovědí viz tabulku 1).

Dotazník měl celkem 24 uzavřených otázek se třemi možnostmi odpovědí typu „multiple choice“. Úvodní otázky a poslední otázka nebyly znalostní, a v níže uvedené analýze proto nebyly hodnoceny. Na základě vyhodnocení těchto dotazníků a zjištění nedostatků v odpovědích jsme se rozhodli ve spolupráci se Záchrannou službou hlavního města Prahy uspořádat pro pacienty a jejich př́buzné edukační seminár o zásadách laické resuscitace. Tento edukační seminář byl uspořádán na naší klinice v únoru 2010, zúčastnilo se ho 16 pacientů a jejich př́ibuzní, celkem bylo 29 účastníků. Pacientům, kteří se nezúčastnili semináře, byla rozeslána edukační brožura „První pomoc nejsou žádné čáry“, kterou vydala právě ZZS HMP. Na začátku dubna 2010 byly pacientům a jejich př́ibuzným znovu rozeslány stejné dotazníky.

Program semináŕe laické resuscitace:

> Klinický obraz náhlé zástavy oběhu

> Jak správně komunikovat se záchrannou službou

Postup a praktický nácvik při laické první pomoci

> Nejčastější omyly při poskytování laické první pomoci

\section{Výsledky}

$\mathrm{V}$ prvním kole před uspořádáním semináře se vrátilo celkem 40 vyplněných dotazníků, tj. jak od pacientů samotných, tak od př́ibuzných, $\mathrm{v}$ druhém kole, po uskutečnění edukačního semináře nebo obdržení edukační brožury, byla návratnost celkem 26 dotazníků. Průměrná správnost odpovědí stoupla v 11 otázkách ze 17 , vědomosti pacientů se tak zlepšily o $64 \%$. U otázky 8 zůstaly odpovědi stejné a u otázek 18 a 19 správnost odpovědí klesla. Vyhodnocení dotazníků je uvedeno v tabulce 1 a na obrázku 1 .

\section{Diskuse}

Kardiopulmonální resuscitace je předpokladem záchrany pacienta $s$ dechovou či oběhovou zástavou. Úspěšnost KPR dlouhodobě dosahuje pouhých $11 \%$. Neustálá edukace široké veřejnosti $v$ technikách provádění KPR je opodstatněná. Proto jsme si dali za cíl edukovat jak naše pacienty, tak i jejich př́buzné, tj. ty, kteří jsou zástavou srdeční př́mo dotčeni a setkali se s takto závažnou př́íhodou at již osobně, nebo u svých nejbližších příbuzných.

Právě tato zkušenost pak umožní cílenou a úspěšnou edukaci. Motivace pro snahu o získání podrobnějších informací je nasnadě a naše zkušenost $s$ úspěšností intervence otevírá možnost edukovat pacienty a jejich př́buzné systematicky. Případně s jejich pomocí pak rozšírit edukaci laiků i na osoby, které se srdeční zástavou bezprostřední zkušenost neměli.

\section{Závěr}

Edukace laické veřejnosti pomocí uspořádání výukového semináře s teoretickou i praktickou částí je relativně jednoduchý způsob, jak rozšírit poznatky o srdeční zástavě u pacientů samotných i u jejich př́buzných. Takovýto postup je vysoce efektivní s prokazatelně lepší teoretickou připraveností laiků po absolvování uvedeného semináře. Považujeme za vhodné zařadit edukaci př́buzných o zásadách KPR do standardu poresuscitační péče.

\section{Literatura}

1. Franěk $O$, Pokorná $M$, Soukupová P. Pre-hospital cardiac arrest in Prague, Czech Republic - the Utstein-style report. Resusc 2010;81:831-835.

2. Evropská rada pro resuscitaci. Kapesní vydání doporučených postupů v resuscitaci 2005. Česká rada pro resuscitaci, 2006. 196 s.

3. Solař M. léčebná hypotermie u nemocných po srdeční zástavě. Interv Akut Kardiol 2004;3:192-195.

4. Kozák M. Náhlá srdeční smrt. Inter Med Praxi 2009;11:211-214.

5. www.resuscitace.cz

6. www.zachrannasluzba.cz 